\title{
MEMBANGUN KEPUASAN NASABAH MELALUI KUALITAS PELAYANAN PADA NASABAH PINJAMAN PT BPR PRIMA KREDIT MANDIRI CABANG CIPUTAT KOTA TANGERANG SELATAN
}

\author{
Udin Ahidin *) \\ e-mail: ahidin.udin@gmail.com \\ Stephany Ribka
}

\begin{abstract}
ABSTRAK
Tujuan penelitian ini untuk mengetahui kualitas pelayanan PT. BPR Prima Kredit Mandiri Cabang Ciputat Tangerang Selatan, Untuk mengetahui tingkat kepuasan nasabah PT. BPR Prima Kredit Mandiri cabang Ciputat Tangerang Selatan, dan untuk mengetahui pengaruh kualitas pelayanan terhadap kepuasan nasabah pada PT. BPR Prima Kredit Mandiri cabang Ciputat Tangerang Selatan.

Metode penelitian yang digunakan adalah metode assosiatif kuantitatif. Populasi dalam penelitian ini nasabah pinjaman sebanayak 4.000 orang. Teknik sampling menggunakan teknik acak sederhana dengan jumlah sampel 98 nasabah. Metode pengumpulan data observasi dan kuesioner. Metode analisis data yang digunakan uji validitas, uji reliabilitas, uji regresi linier sederhana, uji korelasi product moment, uji determinasi, dan uji hipotesis (uji-t).

Hasil penelitian menunjukan bahwa kualitas pelayanan yang diberikan oleh PT. BPR Prima Kredit Mandiri cabang Ciputat Tangerang Selatan dipersepsikan Baik (B). Hal itu dapat dilihat dari nilai rata-rata score variabel kualitas pelayanan sebesar 3,67 ada pada interval 3,40 - 4,19 dengan kategori Baik (B). Kepuasan Nasabah Pinjaman pada PT. BPR Prima Kredit Mandiri cabang Ciputat Tangerang Selatan dipersepsikan Puas (P). Hal itu dapat dilihat dari nilai rata-rata score variabel kepuasan nasabah sebesar 4,03 ada pada interval 3,40 - 4,19 dengan kategori Puas (P). Terdapat pengaruh positif kuat dan signifikan antara kualitas pelayanan terhadap kepuasan nasabah pinjaman PT. BPR Prima Kredit Mandiri cabang Ciputat Tangerang Selatan. Hal itu dapat di lihat dari nilai koefesien regresi linier sederhana $Y=23,7+$ $0,013 X$. Nilai koefesien Korelasi $r=0,654$. Nilai Koefesien Determinasi $R=42,8 \%$ dan nilai $t$ hitung $11,193>\mathrm{t}_{\text {tabel }} 1,6609$.
\end{abstract}

Kata Kunci: Kualitas Pelayanan dan Kepuasan Nasabah

\section{ABSTRACT}

The purpose of this study to determine the quality of service PT. BPR Prima Kredit Mandiri Branch Ciputat South Tangerang, To know the level of customer satisfaction PT. BPR Prima Kredit Mandiri Ciputat branch of South Tangerang, and to know the influence of service quality to customer satisfaction at PT. BPR Prima Kredit Mandiri Ciputat branch of South Tangerang.

The research method used is quantitative assosiative method. The population in the research Customer Loan sebenayak 4000 customers. The sampling technique used a simple random technique with a sample size of 98 customers. Methods of collecting observational data and questionnaires. Data analysis method used validity test, reliability test, simple linear regression test, product moment correlation test, test of determination, and hypothesis test (ttest).

The results showed that the quality of services provided by PT. BPR Prima Kredit Mandiri Ciputat branch of South Tangerang perceived Good (B). It can be seen from the value of the average score of service quality variables of 3.67 is at intervals of 3.40 to 4.19 with Good category (B). Customer Satisfaction Loans at PT. BPR Prima Kredit Mandiri branch of Ciputat Tangerang Selatan perceived Satisfied $(P)$. It can be seen from the average value of customer satisfaction score score of 4.03 is at intervals of 3.40 to 4.19 with the category Satisfied $(P)$. There is a strong and significant positive influence between the quality of service to customer 
satisfaction loans PT. BPR Prima Kredit Mandiri Ciputat branch of South Tangerang. It can be seen from the value of simple linear regression coefficient $Y=23,7+0,013 X$. Coefficient value Correlation $r=0.654$. Coefficient Determination Value $R=42.8 \%$ and $t$ value $11.193>t$ table 1.6609 .

Keywords: Service Quality and Customer Satisfaction

\section{A. Pendahuluan.}

Persaingan di dunia bisnis perbankan sekarang sudah sangat ketat dan kompetitif. Meningkatnya persaingan tersebut ditandai dengan banyaknya jumlah bank dengan variasi produk dan jasa yang ditawarkan oleh bank. Seiring dengan perkembangan zaman, pertumbuhan ekonomi juga mengalami kemajuan yang pesat dari tahun ke tahun karena hal tersebut, secara tidak langsung mendorong pembangunan dan pengembangan masyarakat Indonesia secara menyeluruh. Hal ini tidak terlepas dari campur tangan lembaga keuangan perbankan dalam berbagai sektor ekonomi.

Perkembangan industri perbankan dan jasa keuangan sendiri mengalami kemajuan yang pesat beberapa tahun ini, akibat dari kemajuan teknologi dan beberapa kebijakan regulasi pemerintah. Menyadari hal tersebut, perusahaan perbankan mengambil peluang yang ada. Hal yang dibutuhkan oleh lembaga keuangan bank adalah menjalankan dengan baik peran penting bank tersebut sehingga mendapatkan kepercayaan dari masyarakat. Bukan hanya bank-bank umum, tetapi bank perkreditan rakyat juga berlomba mencari peluang yang ada.

Di dalam perbankan, khususnya Bank Perkreditan Rakyat (BPR) dalam rangka menghadapi persaingan yang kertat, maka perlu memperhatikan taktik dalam strategi pemasaran. Di antara taktik tersebut yang tertuang di dalam bauran produk di antaranya kualitas pelayanan perbankan menjadi indikator yang konkret untuk menciptakan kepercayaan pemahaman masyarakat sebagai nasabah tentang perbankan (IBI, 2014). Nasabah akan memilih bank yang memberikan rasa aman, sekaligus keuntungan pada dana yang mereka tempatkan tanpa adanya rasa curiga. Masyarakat juga akan memilih bank yang mampu memenuhi kebutuhan mereka dan memberikan kemudahan dalam pelayanan dari semua perusahaan perbankan yang ada, nasabah pasti akan memilih bank yang mampu memberikan kualitas yang tinggi dari perusahaan yang lain secara konsisten.

Kualitas pelayanan merupakan salah satu faktor kunci bagi keberhasilan perusahaan jasa dan tidak dapat dipungkiri dalam dunia bisnis saat ini, karena tidak ada yang lebih penting lagi bagi sebuah perusahaan jasa terkecuali menempatkan masalah kepuasan dan loyalitas terhadap nasabah melalui pelayanan sebagai suatu komitmen bisnisnya (Wijayanto,2015).

Untuk mencapai kesepakatan pelayanan dan ketetapan pelayanan yang diberikan, pelayanan yang baik juga perlu didukung oleh ketersediaan dan kelengkapan produk yang dibutuhkan nasabah, dan untuk kemajuan perusahaan perbankan maka perlu mencermati permintaan konsumen terhadap suatu produk dan jasa yang akan ditawarkan, salah satunya yaitu dengan meningkatkan pelayanan pada perusahaan perbankan itu sendiri. Dalam hal kualitas pelayanan sering terdengar suara dari para nasabah yang mengatakan bahwa pelayanan dari 
suatu bank sangat tidak memuaskan.Yang sering terjadi adalah kurangnya respon dan lambatnya seorang karyawan bank dalam melaksanakan tugasnya melayani nasabah. Karyawan bank yang sering datang terlambat berakibat kinerja karyawan menjadi tidak optimal. Kemudian dari karyawan frontliner yang seharusnya sudah siap berada ditempatnya sebelum jam operasional kantor dimulai, tetapi masih terjadi keterlambatan datangnya karyawan dari Frontliner tersebut, sehingga menyebabkan pelayanan bank yang belum optimal.

Fenomenal tersebut terjadi pada PT. BPR Prima Kredit Mandiri Cabang Ciputat Tangerang Selatan sebagai tempat penelitian. Masyarakat yang semakin kritis saat ini, sehingga ketika bank yang selama ini diharapkan ada, ternyata kehadirannya tidak sesuai dengan apa yang diinginkan. Itu semua akan berakibat kehilangan kepercayaan masyarakat terhadap bank itu sendiri. Sedangkan bank merupakan Agent of Trust (IBI, 2013). PT. BPR Prima Kredit Mandiri cabang Ciputat Tangerang Selatan sebagai salah satu lembaga perbankan, harus mampu memberikan pelayanan yang berkualitas untuk memberikan kepuasan bagi nasabahnya sehingga akan meningkatkan volume usahanya dan sekaligus meningkatkan laba. Sebagai langkah untuk memberikan kualitas pelayanan yang bisa memuaskan nasabahnya, PT. BPR Prima Kredit Mandiri cabang Ciputat Tangerang Selatan harus bisa inovatif dan berorientasi pada setiap kebutuhan nasabahnya.

Berdasarkan studi pendahuluan (pra riset) yang penulis lakukan dilapangan, yaitu di PT BPR Prima Kredit Mandiri cabang Ciputat Tangerang Selatan, ditemukan fenomena-fenomena menarik untuk diteliti lebih lanjut sehingga menghasilkan sebuah informasi yang bermanfaat. Fenomena tersebut seperti pada tabel dibawah ini :

Tabel 1.1

Data Dana Pinjaman

PT. BPR Prima Kredit Mandiri Cabang Ciputat Tangerang Selatan

\begin{tabular}{|c|c|c|c|}
\hline Tahun & Jumlah Dana & $\begin{array}{c}\text { Perkembangan } \\
\qquad \boldsymbol{\Delta}]\end{array}$ & $\begin{array}{c}\text { Persen } \\
(\%)\end{array}$ \\
\hline 2012 & Rp-13 Milyar & - & - \\
\hline 2013 & Rp-14 Milyar & 1 Milyar & $1,51 \%$ \\
\hline 2014 & Rp-16 Milyar & 2 Milyar & $3,03 \%$ \\
\hline 2015 & Rp-13 Milyar & -3 Milyar & $-4,55 \%$ \\
\hline 2016 & Rp-10 Milyar & -3 Milyar & $-4,55 \%$ \\
\hline Total & Rp. 66 Milyar & - & - \\
\hline
\end{tabular}

Berdasarkan data tabel 1.1 di atas didapat informasi bahwa dana pinjaman PT. BPR Prima Kredit Mandiri cabang Ciputat Tangerang Selatan selama 5 tahun terakhir mengalami fluktuatif. Ini mengindikasikan bahwa tingkat kepuasan nasabah PT. BPR Prima Kredit Mandiri cabang Ciputat Tangerang Selatan juga fluktuatif.

Fluktuasinya tingkat kepuasan nasabah PT. BPR Prima Kredit Mandiri cabang Ciputat Tangerang Selatan diduga disebabkan oleh tingkat kualitas pelayanan yang 
belum optimal. Fenomena yang terjadi terkait kualitas pelayanan tersebut dapat di lihat pada tabel 1.2. di bawah ini:

Tabel 1.2

Data Sarana Pelayanan (Tangible)

PT. BPR Prima Kredit Mandiri cabang Ciputat Tangerang Selatan

\begin{tabular}{|c|c|c|c|}
\hline No & $\begin{array}{c}\text { Sarana Pelayanan } \\
\text { (Tangible) }\end{array}$ & $\begin{array}{l}\text { Standar Sarana } \\
\text { Pelayanan }\end{array}$ & Riil \\
\hline 1 & Tempat Parkir & $\begin{array}{l}\text { Luas untuk parkir } \\
\text { mobil }\end{array}$ & Sempit untuk parkir mobil \\
\hline 2 & $\mathrm{AC}$ & Dingin & kurang dingin \\
\hline 3 & Buang Tunggu & @ orang : $1,0 \times 1,5 \mathrm{~m}$ & (1) orang : $1,0 \times 1.0 \mathrm{~m}$ \\
\hline 4 & Informasi Perbankan & Terpublikasikan & $\begin{array}{l}\text { Sebagian tidak } \\
\text { dipublikasi }\end{array}$ \\
\hline 5 & Gedung & $\begin{array}{c}\text { Bisa diakses dari } \\
\text { berbagai arah } \\
\text { kendaraan }\end{array}$ & $\begin{array}{c}\text { Tidak semua arah } \\
\text { kendaraan dapat } \\
\text { mengakses }\end{array}$ \\
\hline
\end{tabular}

Sumber: Hasil Observasi di PT.BPR Prima Kredit Mandiri cabang Ciputat Tangerang Selatan (2017)

Berdasarkan data tabel di atas didapat informasi bahwa sarana pelayanan (Tangible) yang merupakan salah satu dimensi kualitas pelayanan yang dimiliki PT. BPR Prima Kredit Mandiri cabang Ciputat Tangerang Selatan masih belum sesuai dengan standar sarana pelayanan bank. Oleh karena itu kualitas pelayanan menjadi isu dalam penelitian ini yang diduga merupakan penyebab kepuasan nasabah terjadi fluktuatif selama 5 tahun terakhir.

Berdasarkan paparan latar belakang di atas, maka penulis tertarik untuk melakukan penelitian dengan judul: "Pengaruh Kualitas Pelayanan Terhadap Kepuasan Nasabah Pinjaman Pada PT. BPR Prima Kredit Mandiri cabang Ciputat Tangerang Selatan".

\section{B. Perumusan Masalah}

Sesuai dengan latar belakang di atas, agar pembahasan penelitian fokus pada permasalahan, maka dapat penulis susun rumusan masalah sebagai berikut:

1. Bagaimana kualitas pelayanan PT. BPR Prima Kredit Mandiri cabang Ciputat Tangerang Selatan?

2. Bagaimana kepuasan nasabah terhadap pelayanan PT. BPR Prima Kredit Mandiri cabang Ciputat Tangerang Selatan?

3. Apakah terdapat pengaruh kualitas pelayanan terhadap kepuasan nasabah pada PT. BPR Prima Kredit Mandiri cabang Ciputat Tangerang Selatan?

\section{Tujuan Penelitian}

1. Untuk mengetahui secara empiris kualitas pelayanan PT. BPR Prima Kredit Mandiri cabang Ciputat Tangerang Selatan. 
2. Untuk mengetahui secara empiris kepuasan nasabah pinjamanan PT. BPR Prima Kredit Mandiri cabang Ciputat Tangerang Selatan.

3. Untuk mengetahui secara empiris pengaruh kualitas pelayanan terhadap kepuasan nasabah pinjaman PT. BPR Prima Kredit Mandiri cabang Ciputat Tangerang Selatan.

\section{Landasan Teori}

Pandangan tentang konsep kualitas (quality) menurut Sallis (2011:30), bahwa kualitas merupakan suatu hal yang membedakan yang baik dan sebaliknya. Pendapat tersebut diperjelas oleh Tjiptono (2008:67) bahwa kualitas adalah cerminan semua dimensi penawaran produk yang menghasilkan manfaat (benefit) bagi pelanggan.

Di sisi lain Fandy Tjiptono (2008) menjelaskan bahwa setelah melakukan evaluasi dari definisi yang sering dikemukakan terhadap konsep kualitas, definisidefinisi kualitas tersebut adalah sebagai berikut :

1) Kesesuaian dengan persyaratan atau tuntutan

2) Kecocokan untuk pemakaian

3) Perbaikan atau penyempurnaan berkelanjutan

4) Bebas dari kerusakan atau cacat

5) Pemenuhan kebutuhan pelanggan semenjak awal dan setiap saat

6) Melakukan segala sesuatu secara benar semenjak awal dan

7) Sesuatu yang bisa membahagiakan pelanggan.

Perihal kualitas pelayanan menurut Angelova dan Zekiri (2011:238) menyatakan bahwa perceived service quality is a global judgment, or attitude, relating to the superiority of the sevice, whereas satisfaction is related to a speacific transaction. Kualitas pelayanan adalah penilaian global, atau sikap berkaitan dengan keunggulan pada layanan, sedangkan kepuasan berkaitan dengan transaksi tertentu. Salah satu cara yang dapat dilakukan untuk mempertahankan sebuah perusahaan jasa adalah dengan memberika prioritas pelayanan yag lebih baik dari pesaing secara terus-menerus dan memenuhi harapan konsumen. Bila kualitas pelayanan yang dirasakan lebih kecil dari pada yang diharapkan maka konsumen menjadi tidak tertarik pada perusahaan jasa tersebut, akan tetapi apabila yang terjadi adalah sebaliknya ada konsumen akan terus-menerus menggunakan kembali jasa perusahaan tersebut.

Pendapat di atas sejalan dengan Fogli (2006) described service quality as "a global judgment or attitude that has a link to a particular service, the overall notion of the relative inferiority or superiority of the organizations' services. Menggambarkan kualitas layanan sebagai "keputusan global atau sikap yang memiliki link ke layanan tertentu, gagasan keseluruhan dari inferioritas relatif atau keunggulan 'layanan organisasi.

Berdasarkan uraian di atas dapat penulis simpulkan bahwa, kualitas pelayanan adalah penyampaian pelayanan secara "excellent" atau "superior" dibandingkan dengan harapan nasabah. 
Sebuah perusahaan jasa harus dapat memberikan pelayanan yang berkualitas tinggi secara konsisten dan continue dibandingkan dengan pesaing, dalam rangka memenuhi harapan pelanggan. Usaha jasa terbilang cukup rumit dan sangat kompleks daripada barang yang mempunyai wujud konkret, sehingga menyulitkan seseorang untuk mengidentifikasinya dalam waktu yang singkat.

Menurut Parasuraman, Zeithamal \& Bery dalam Kertajaya (2015) bahwa untuk mengukur kualitas pelayanan yang dirasakan secara nyata oleh konsumen, maka dapat diukur oleh dimensi yang dikenal dengan RATER (Reliability, Assurance, Tangible, Empathy, dan Responsiveness). Penjelasan tentang RATER tersebut sebagai berikut:

1) Reliability, dalam bahasa sederhana dapat diartikan sebagai kemampuan perusahaan untuk menyampaikan service sesuai dengan yang dijanjikan secara konsisten dan akurat. Reliabilitas ini adalah elemen pertama dan utama yang perlu diperhatikan Marketers dalam menjalin hubungan jangka panjang dengan pelanggan.

2) Assurance, dapat diartikan sebagai pengetahuan dan keramahan pemberi layanan dan kemampuan untuk menumbuhkan kepercayaan pelanggan. Elemen ini sangat mempengaruhi persepsi pelanggan kepada kita. Kita sering kali menemui keluhan pelanggan "hanya" karena pemberi layanan bersikap judes kepada pelanggan, padahal elemen lainnya sudah benar-benar baik. Inilah yang membuat assurance penting untuk diperhatikan.

3) Tangible, elemen ini merefleksikan pada fasilitas fisik, peralatan, sampai dengan penampilan staf. Meskipun terkesan remeh, tapi pengelolaan yang yang buruk dapat menimbulkan citra negatif pada pelanggan. Apa Anda mau dirawat di rumah sakit yang jorok atau makan di restoran yang banyak tikusnya ? tentu tidak. Oleh sebab itu, keterbatasan jangan sampai membuat kita malas merawat aspek tangible dari service yang kita berikan.

4) Empathy, merupakan perhatian lebih dan personal yang diberikan pemberi layanan kepada pelanggannya. Bila dilakukan dengan benar, empathy dapat meninggalkan kesan mendalam. Ini cenderung "murah" karena hanya bermodal ketulusan tapi berdampak besar. Hal ini sangat cocok diperhatikan di masa penuh tantangan seperti saat ini.

5) Responsiveness, merupakan kemauan untuk memberikan service tepat waktu kepada pelanggan sehingga pelanggan mendapatkan segala sesuatu sesuai 
dengan kondisi yang dihadapi. Elemen ini semakin penting karena di era perkembangan teknologi informasi seperti ini pelanggan semakin menuntut untuk mendapatkan service dengan lebih mudah, cepat, dan praktis.

Menurut Kotler (2013), bahwa kepuasan pelanggan adalah perasaan senang atau kecewa seorang pelanggan setelah membandingkan antara kinerja harapan dan kinerja riil. Jika kinerja harapan sama dengan kinerja riil pelanggan puas. Jika kinerja harapan lebih kecil dari kinerja riil pelanggan sangat puas atau senang. Jika kinerja harapan lebih besar dari kinerja rill pelanggan tidak puas.

Pendapat di atas diperkuat oleh Hasan (2013), menjelaskan bahwa kepuasan pelanggan merupakan sebuah perasaan dan sikap seseorang dalam menggunakan sebuah produk atau jasa. Sehingga muncul sebuah evaluasi terhadap kinerja produk atau jasa tersebut.

Perihal kepuasan pelanggan diperjelas juga oleh oleh Fandy Tjiptono (2008) menyatakan bahwa kepuasan pelanggan merupakan evaluasi purnabeli di mana alternatif yang dipilih sekurang-kurangnya sama atau melampaui harapan pelanggan. Di lihat dari berbagai definisi yang penulis baca, penulis menyimpulkan bahwa adanya perbedaan antara apa yang diinginkan pelanggan dengan apa yang dirasakan oleh pelanggan. Harapan pelanggan dapat dibentuk oleh pengalaman masa lampau, opini dari orang lain, dan informasi yang diterima.

berdasarkan definisi di atas dapat disimpulkan bahwa pada dasarnya kepuasan pelanggan mencakup perbedaan antara harapan dan kinerja atau hasil yang dirasakan. Apabila kinerja di bawah harapan, maka pelanggan akan kecewa, jika harapan sama dengan kinerja riil pelanggan puas, dan jika harapan lebih kecil dari kinerja riil maka pelanggan sangat puas atau senang.

Menurut Kotler (2009) metode yang dapat dipergunakan setiap perusahaan untuk memantau dan mengukur kepuasan pelanggan adalah sebagai berikut :

1) Sistem Keluhan dan Saran

Organisasi yang berwawasan pelanggan akan membuat pelanggannya memberikan saran atau keluhan, misalnya dengan memberikan formulir bagi pelanggan untuk melaporkan kesukaan atau keluhan.Alur informasi ini memberikan banyak gagasan baik dan perusahaan dapat bergerak lebih cepat untuk menyelesaikan masalah.

2) Survei Pelanggan 
Kepuasan pelanggan dapat diukur melalui persepsi pelanggan terhadap kepuasannya.

3) Pembeli Bayangan

Cara lain untuk mengukur mengenai kepuasan pelanggan adalah dengan menyuruh orang berpura-pura menjadi pembeli dan melaporkan titik kuat maupun lemah yang mereka alami sewaktu membeli produk.

4) Analisa Kehilangan Pelanggan

Perusahaan seyogyanya menghubungi para pelanggan yang telah berhenti membeli atau telah pindah pemasok agar dapat memahami mengapa hal ini terjadi dan supaya dapat mengambil kebijakan perbaikan atau penyempurnaan selanjutnya.

Menurut Winkel (2014), bahwa kepuasan pelanggan dapat diukur oleh dimensidimensi sebagai berikut:

1. Sikap/keyakinan (Kognitif)

Keadaan diri di mana manusia dapat merespon baik atau tidaknya suatu pelayanan yang diberikan oleh perusahaan.

2. Emosi atau perasaan (Afektif)

Perasaan intens yang ditunjukan seseorang atau sesuatu yang dapat memberikan kesan puas terhadap pelayanan yang diberikan perusahaan kepada konsumen nya sebagai pelanggan.

3. Perilaku/tindakan (Konatif)

Sikap kecenderungan terhadap stimulus tertentu tentang bagaimana kepercayaan yang diaplikasikan dalam perilaku pelanggan

Berdasarkan pemaparkan di atas, maka terbentuk sebuah kerangka pemikiran di dalam penelitian seperti pada gambar 1.1 di bawah ini:

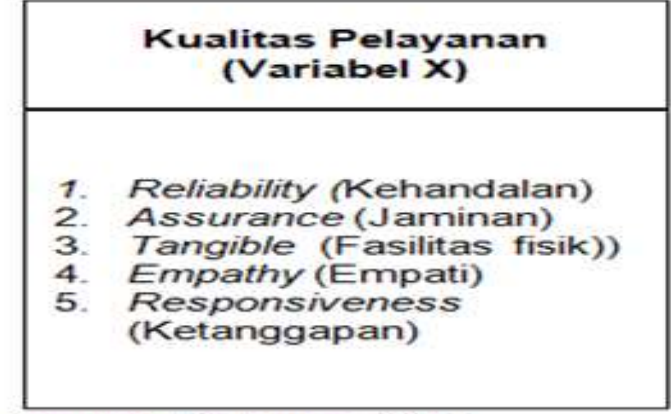

Sumber: Kertajaya (2015)

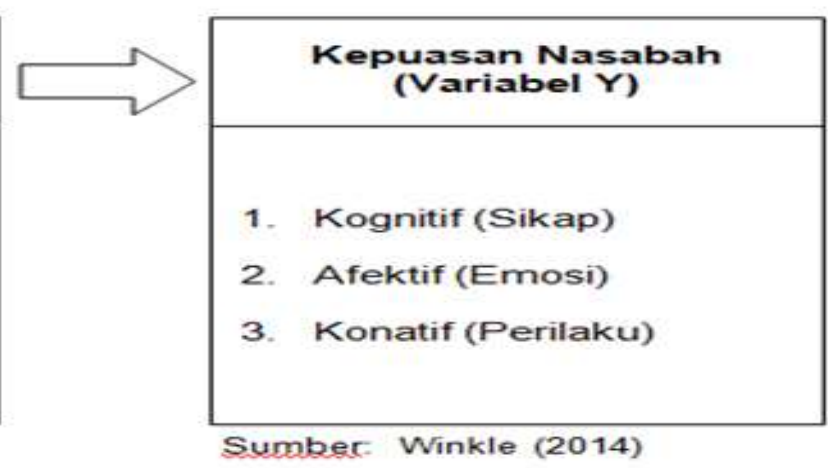

Gambar 1.1 Kerangka Berpikir 
Berdasarkan asumsi yang dikemukakan dalam rumusan masalah dan kerangka pemikiran di atas, maka hipotesis pada penelitian ini sebagai berikut:

$\mathrm{Ho}=$ Tidak terdapat pengaruh yang positif dan signifikan antara kualitas pelayanan terhadap tingkat kepuasan nasabah PT. BPR Prima Kredit Mandiri cabang Ciputat Tangerang Selatan.

$\mathrm{Ha}=$ Terdapat pengaruh positif dan signifikan antara kualitas pelayanan terhadap tingkat kepuasan nasabah PT. BPR Prima Kredit Mandiri cabang Ciputat Tangerang Selatan.

\section{E. Metodologi}

Unit analisis dalam penelitian ini PT. BPR Prima Kredit Mandiri cabang Ciputat Tangerang Selatan. Institusi ini merupakan perusahaan swasta yang bergerak dibidang perbankan, yang beralamat di JL. Dewi Sartika Kav 3 No. 8 B Ciputat, Tangerang Selatan. Unit observasi dalam penelitian ini nasabah pinjaman PT. BPR Prima Kredit Mandiri cabang Ciputat Tangerang Selatan. Jenis penelitian ini assosiatif kuantitatif.

Populasi dalam penelitian ini nasabah pinjaman PT. BPR Prima Kredit Mandiri cabang Ciputat Tangerang Selatan sebanyak 4000 nasabah yang diambil dari data nasabah pinjaman di akhir Tahun 2016.

Sampel dalam penelitian ini menggunakan teknik random sampling (acak sederhana) dan insidential sampling (yang mudah dihubungi). Sedangkan penentuan jumlah sampel menggunakan rumus Slovin, sehingga didapat jumlah sampel 98 responden/nasabah.

Metode pengumpulan data dengan menggunakan observasi semi aktif yaitu penulis terjun langsung ke objek penelitian sebagian melakukan seperti subjek dan objek yang sedang diteliti, dan sebagian hanya menerima data yang sudah jadi (data sekunder) untuk dianalisis. Untuk mendapatkan data terkait eksistensi variabel judul, maka penulis menggunakan teknik penyebaran kuesioner dengan menggunakan skala likert dan skala interval.

Metode Uji kelayakan data dalam penelitian ini penulis menggunakan uji validitas terhadap instrumen pernyataan kuesioner. Hasil uji validitas dapat disajikan pada tabel di bawah ini:

Tabel 3.1

\begin{tabular}{l} 
Hasil Perhitungan Uji Validitas Instrumen Variaberl Kualitas Pelayanan \\
\hline No
\end{tabular}


Tabel 3.2

Hasil Perhitungan Uji Validitas Instrumen Variabel Kepuasan Nasabah

\begin{tabular}{|c|c|c|c|}
\hline No & r-hitung & r-tabel & Kesimpulan \\
\hline 1 & 0,702 & 0,165 & Valid \\
\hline 2 & 0,743 & 0,165 & Valid \\
\hline 3 & 0,552 & 0,165 & Valid \\
\hline 4 & 0,537 & 0,165 & Valid \\
\hline 5 & 0,781 & 0,165 & Valid \\
\hline 6 & 0,744 & 0,165 & Valid \\
\hline
\end{tabular}

Sumber: Data Hasil Olahan (2017)

Uji kelayakan lainnya dalam penelitian ini penulis mennggunakan uji reliabilitas. Hasil uji reliabilitas dapat penulis sajikan pada tabel di bawah ini:

Tabel. 3.3

Hasil Perhitungan Uji Reliabilitas

\begin{tabular}{|c|c|c|c|c|}
\hline No & Variabel & r hitung & r kritis & Keterangan \\
\hline 1. & Kualitas Pelayanan & 0,983 & 0,60 & reliabel \\
\hline 2. & Kepuasan Nasabab & 0,941 & 0,60 & reliabel \\
\hline
\end{tabular}

Sumber: Data Olahan (2017)

Berdasarkan hasil perhitungan uji validitas dan uji reliabilitas di atas, maka seluruh instrumen kuesioner dinyatakan valid dan reliabel semua. Sehingga layak untuk dijadikan alat ukur untuk mengukur variabel kualitas pelayanan dan kepuasan pelanggan.

F. Hasil dan Pembahasan

Di dalam pembahasan hasil penelitian ini penulis menjawab rumusan masalah di Bab I yang diajukan sehingga fokus pada rumusan masalah. Jawaban atas rumusan masalah tersebut sebagai berikut:

\section{a. Kualitas Pelayanan PT. BPR Prima Kredit Mandiri cabang Ciputat Tangerang Selatan}

Untuk mengetahui kualitas pelayanan yang diberikan oleh PT. BPR Prima Kredit Mandiri cabang Ciputat Tangerang Selatan, maka di bawah ini disajikan analisis statistik deskriftif, sehingga bisa menjawab rumusan masalah nomor 1 (satu) persepsi konsumen bank dalam hal ini nasabah sebagai berikut: 
Tabel 4.1

Komposisi Jawaban Variabel Kualitas Pelayanan (X)

\begin{tabular}{|c|c|c|c|c|c|c|c|c|c|c|}
\hline & \multirow{3}{*}{ Pernyataan } & \multicolumn{5}{|c|}{ Jawaban dan Bobot } & \multirow{3}{*}{ Total } & \multirow{3}{*}{$\begin{array}{c}\text { Sam } \\
\text { pel }\end{array}$} & \multirow{3}{*}{$\begin{array}{l}\text { Rata- } \\
\text { rata }\end{array}$} & \multirow{3}{*}{ Kategori } \\
\hline & & SB & B & KB & TB & STB & & & & \\
\hline & & 5 & 4 & 3 & 2 & 1 & & & & \\
\hline $\begin{array}{l}\mathbf{N} \\
\mathbf{0}\end{array}$ & \multicolumn{10}{|l|}{ Tangible (Bukti Fisik) } \\
\hline 1. & $\begin{array}{l}\text { BPR PKM cabang Ciputat } \\
\text { memiliki ruang tunggu yang } \\
\text { luas, nyaman dan bersih }\end{array}$ & 31 & 46 & 9 & 9 & 3 & 387 & 98 & 3,95 & Baik (B) \\
\hline \multirow[t]{3}{*}{2} & $\begin{array}{l}\text { Gedung BPR PKM cabang } \\
\text { Ciputat dapat diakses dari } \\
\text { berbagai arah kendaraan }\end{array}$ & 27 & 36 & 15 & 12 & 8 & 356 & 98 & 3,63 & Baik (B) \\
\hline & \multicolumn{6}{|c|}{ Rata-Rata Score Dimensi Tangible (Bukti Fisik) } & 743 & 196 & 3,79 & Baik (B) \\
\hline & Reliability (Kehandalan) & & & & & & & & & \\
\hline 3. & $\begin{array}{c}\text { BPR PKM cabang Ciputat } \\
\text { memberikan informasi kepada } \\
\text { nasabah dengan tepat }\end{array}$ & 9 & 68 & 12 & 3 & 6 & 365 & 98 & 3,72 & Baik (B) \\
\hline \multirow[t]{3}{*}{4.} & $\begin{array}{l}\text { BPR PKM cabang Ciputat selalu } \\
\text { memudahkan teknis pelayanan } \\
\text { kepada nasabah }\end{array}$ & 15 & 28 & 34 & 21 & 0 & 331 & 98 & 3,37 & $\begin{array}{l}\text { Kurang } \\
\text { Baik (KB) }\end{array}$ \\
\hline & \multicolumn{6}{|c|}{ Rata-Rata Score Dimensi Reliability (Kehandalan) } & 696 & 196 & 3,55 & Baik (B) \\
\hline & $\begin{array}{c}\text { Responsiveness } \\
\text { (Ketanggapan) }\end{array}$ & & & & & & & & & \\
\hline 5. & $\begin{array}{c}\text { BPR PKM cabang Ciputat cepat } \\
\text { tanggap dalam melayani } \\
\text { keluhan nasabah }\end{array}$ & 31 & 28 & 24 & 12 & 3 & 366 & 98 & 3,73 & Baik (B) \\
\hline \multirow[t]{3}{*}{6.} & $\begin{array}{c}\text { BPR PKM cabang Ciputat selalu } \\
\text { memberikan respon jika } \\
\text { mendapat kritik dari nasabah }\end{array}$ & 31 & 22 & 22 & 14 & 9 & 346 & 98 & 3,53 & Baik (B) \\
\hline & \multicolumn{6}{|c|}{ Rata-Rata Score Dimensi Responsiveness (Ketanggapan) } & 712 & 196 & 3,63 & Baik (B) \\
\hline & Assurance (Jaminan) & & & & & & & & & \\
\hline 7. & $\begin{array}{l}\text { BPR PKM cabang Ciputat } \\
\text { mampu menyimpan data } \\
\text { dengan benar dan akurat }\end{array}$ & 31 & 28 & 24 & 12 & 3 & 365 & 98 & 3,72 & Baik (B) \\
\hline 8. & $\begin{array}{c}\text { Pegawai BPR PKM cabang } \\
\text { Ciputat memiliki kompetensi di } \\
\text { bidang perbankan }\end{array}$ & 31 & 22 & 22 & 14 & 9 & 398 & 98 & 4,06 & Baik (B) \\
\hline & Rata-Rata Score Din & nsi & urar & Jami & & & 763 & 196 & 3,89 & Baik (B) \\
\hline
\end{tabular}

Vol. 1 No. 2 / Januari 2018 
Manajemen Pemasaran ISSN No. (PRINT) 2598-0823, (ONLINE) 2598-2893

\begin{tabular}{|c|c|c|c|c|c|c|c|c|c|c|}
\hline 9. & Emphaty (Empati) & & & & & & & & \\
\hline $\begin{array}{c}\text { BPR PKM cabang Ciputat } \\
\text { memahami kebutuhan dan } \\
\text { keinginan nasabah }\end{array}$ & 35 & 30 & 21 & 6 & 6 & 376 & 98 & 3,83 & Baik (B) \\
\hline 10 & $\begin{array}{c}\text { BPR PKM cabang Ciputat selalu } \\
\text { peduli dengan nasabah }\end{array}$ & 18 & 21 & 33 & 14 & 12 & 313 & 98 & 3,19 & $\begin{array}{c}\text { Kurang } \\
\text { Baik (KB) }\end{array}$ \\
\hline & $\begin{array}{c}\text { Rata-Rata Score Dimensi Emphaty (Empati) } \\
\text { Rata-Rata Score Variabel } \\
\text { Kualitas Pelayanan }\end{array}$ & $\mathbf{2 1 5}$ & $\mathbf{4 2 1}$ & $\mathbf{2 0 3}$ & $\mathbf{9 4}$ & $\mathbf{4 7}$ & $\mathbf{3 6 0 3}$ & $\mathbf{9 8 0}$ & $\mathbf{3 , 6 7}$ & Baik (B) \\
\hline
\end{tabular}

Sumber : Data Hasil Olahan (2017)

Berdasarkan hasil analisis deskriptif di atas didapat informasi bahwa variabel kualitas pelayanan dipersepsikan Baik (B) oleh nasabah. Hal itu dapat dilihat dari nilai rata-rata score variabel kualitas pelayanan sebesar 3,67 ada pada interval 3,40 - 4,19 dengan kategori Baik (B).

\section{b. Kepuasan Nasabah PT. BPR Prima Kredit Mandiri cabang Ciputat Tangerang Selatan}

Untuk mengetahui kepuasan nasabah PT. BPR Prima Kredit Mandiri cabang Ciputat Tangerang Selatan, maka di bawah ini disajikan analisis statistik deskriftif, sehingga bisa menjawab rumusan masalah nomor 2 (dua) persepsi konsumen bank dalam hal ini nasabah sebagai berikut:

Tabel 4.2

Komposisi Jawaban Variabel Kepuasan Nasabah (Y)

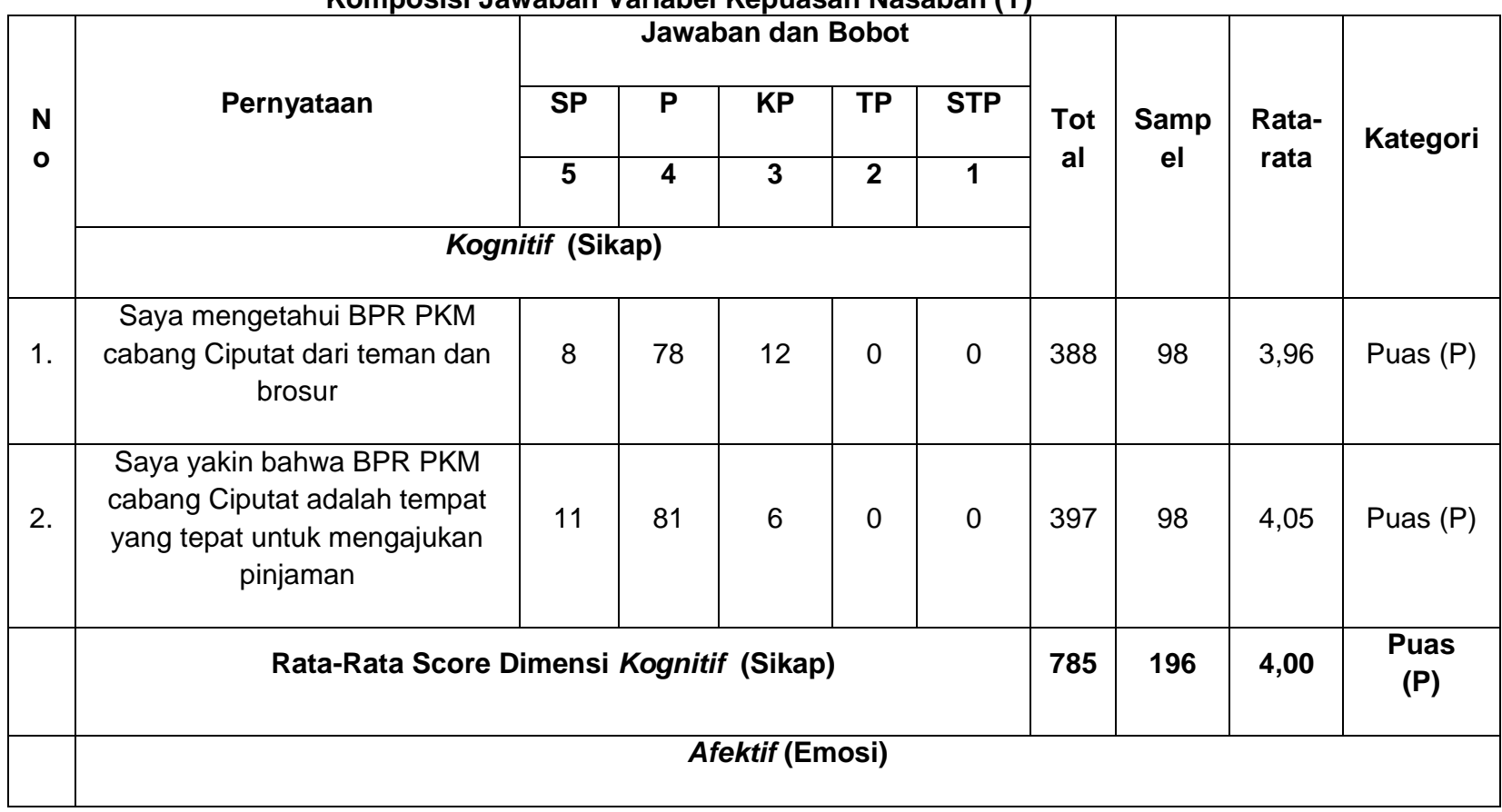

Vol. 1 No.2 / Januari 2018 
Manajemen Pemasaran ISSN No. (PRINT) 2598-0823, (ONLINE) 2598-2893

\begin{tabular}{|c|c|c|c|c|c|c|c|c|c|c|}
\hline 3. & $\begin{array}{c}\text { Saya merasa senang menjadi } \\
\text { nasabah di BPR PKM cabang } \\
\text { Ciputat }\end{array}$ & 20 & 75 & 3 & 0 & 0 & 409 & 98 & 4,17 & Puas $(\mathrm{P})$ \\
\hline 4. & $\begin{array}{l}\text { Persyaratan untuk mengajukan } \\
\text { pinjaman di BPR PKM cabang } \\
\text { Ciputat dirasakan mudah }\end{array}$ & 10 & 84 & 4 & 0 & 0 & 398 & 98 & 4,06 & Puas (P) \\
\hline & \multicolumn{6}{|c|}{ Rata-Rata Score Dimensi Afektif (Emosi) } & 807 & 196 & 4,11 & Puas (P) \\
\hline & \multicolumn{10}{|c|}{ Konatif (Perilaku) } \\
\hline 5. & $\begin{array}{c}\text { Saya akan memberikan } \\
\text { rekomendasi kepada keluarga, } \\
\text { teman atau rekan anda untuk } \\
\text { menjadi nasabah di BPR PKM } \\
\text { cabang Ciputat }\end{array}$ & 13 & 73 & 12 & 0 & 0 & 393 & 98 & 4,01 & Puas (P) \\
\hline 6. & $\begin{array}{c}\text { Saya akan mengajukan } \\
\text { pinjaman lagi di BPR PKM } \\
\text { cabang Ciputat setelah } \\
\text { pinjaman pertama saya telah } \\
\text { selesai }\end{array}$ & 15 & 70 & 9 & 4 & 0 & 390 & 98 & 3,98 & Puas $(P)$ \\
\hline & \multicolumn{6}{|c|}{ Rata-Rata Score Dimensi Konatif (Perilaku) } & 783 & 196 & 3,99 & Puas (P) \\
\hline & $\begin{array}{c}\text { Rata-Rata Score Variabel } \\
\text { Kepuasan Nasabah }\end{array}$ & 77 & 461 & 46 & 4 & 0 & 2375 & 588 & 4,03 & Puas (P) \\
\hline
\end{tabular}

Sumber : Data Hasil Olahan (2017)

Berdasarkan hasil analisis deskriptif di atas didapat informasi bahwa variabel kepuasan nasabah dipersepsikan Puas $(P)$. Hal itu dapat dilihat dari nilai rata-rata score variabel kepuasan nasabah sebesar 4,03 ada pada interval 3,40 - 4,19 dengan kategori Puas $(\mathrm{P})$.

\section{c. Pengaruh Kualitas Pelayanan Terhadap Kepuasan Nasabah PT. BPR Prima}

\section{Kredit Mandiri cabang Ciputat Tangerang Selatan}

Untuk mengetahui pengaruh kualitas pelayanan terhadap kepuasan nasabah PT. BPR Prima Kredit Mandiri cabang Ciputat Tangerang Selatan, maka di bawah ini disajikan analisis statistik inferensia, sehingga bisa menjawab rumusan masalah nomor 3 (tiga) sebagai berikut:

\section{1) Hasil Uji Regresi Linier Sederhana}

Model persamaan regresi linier sederhana sebagai berikut:

$Y=a+b X$ 
Dimana :

$\mathrm{Y} \quad$ = Subyek dalam variabel dependen yang dipresentasikan .

a $=$ Harga $\mathrm{Y}$ bila $\mathrm{X}=0$ (konstanta)

b = Angka arah koefisien regresi, yang menunjukan angka peningkatan ataupun penurunan variabel independen, bila terdapat b (+) maka kepuasan nasabah naik dan bila terdapat b (-) maka kepuasan nasabah terjadi penurunan.

$\mathrm{X}=$ Subyek pada variabel independen yang mempunyai nilai tertentu dalam hal ini kualitas pelayanan

a. Mencari Konstanta

$$
\begin{aligned}
& =\frac{\left(\sum y\right)\left(\sum x^{2}\right)-\left(\sum x\right)-\left(\sum x y\right)}{n\left(\sum x^{2}\right)-\left(\sum x\right)^{2}} \\
= & \frac{(2374)(139186)-(3578)(86793)}{98(139186)-(3578)^{2}} \\
= & \frac{(330427564)-(310545354)}{(13640228)-(12802084)} \\
= & \frac{19882210}{838144} \\
a & =23,7
\end{aligned}
$$

b. Mencari Koefisien Regresi

$$
\begin{aligned}
& =\frac{\left.n\left(\sum x y\right)-\left(\sum x\right) Q 2 y\right)}{n\left(\sum x^{2}\right)-\left(\sum x\right)^{2}} \\
& =\frac{98(86793)-(3578)(2374)}{98(139186)-(3578)^{2}} \\
& =\frac{(8505714)-(8494172)}{(13640228)-(12802084)} \\
& =\frac{11542}{839144} \\
& \text { b }=0,013
\end{aligned}
$$

Dari hasil perhitungan di atas, maka persamaan regresi linier sederhana, kualitas pelayanan terhadap kepuasan nasabah terdapat hasil perhitungan $Y=23,7$ $+0,013 X$, hal tersebut menunjukan bahwa bila nilai $X$ (kualitas pelayanan) diturunkan atau dinaikan 1\% maka akan mempengaruhi peningkatan atau penurunan niai $Y$ (kepuasan nasabah) sebesar 0,013\%.. Sehingga dari hasil 
perhitungan di atas dapat disimpulkan bahwa terdapat pengaruh positif antara kualitas pelayanan terhadap kepuasan nasabah PT. BPR Prima Kredit Mandiri cabang Ciputat Tangerang Selatan.

\section{2). Hasil Uji Korelasi Product Moment}

Uji korelasi product moment digunakan untuk mengetahui seberapa kuat hubungan variabel kualitas pelayanan terhadap kepuasan nasabah. Analisis dan perhitungannya seperti uraian di bawah ini :

$$
r x y=\frac{\left.n \sum x y-c \sum x \sum \sum y\right)}{\sqrt{n \sum X^{2}-}\left(\sum X\right)^{2} \sqrt{n \sum Y^{2}-\left(\sum Y\right)^{2}}}
$$

Diketahui :

$$
\begin{aligned}
& r=\text { (Nilai koefisien korelasi antara } x \text { dan } y) \\
& n=98 \text { (Jumlah sampel) } \\
& x=3578 \text { (Total skor variabel kualitas pelayanan) } \\
& y=2374 \text { (Total skor variabel kepuasan nasabah) } \\
& x^{2}=139186 \text { (Kuadrat variabel kualitas pelayanan) } \\
& y^{2}=57888 \text { (Kuadrat variabel kepuasan nasabah) } \\
& x y=86793 \text { (Jumlah perkalihan skor dan total skor) }
\end{aligned}
$$

$$
\begin{aligned}
\mathrm{rxy} & =\frac{98.86793-(3578) \cdot(2374)}{\sqrt{98.139186-(3578)^{2}\left(98.57888-(2374)^{2}\right.}} \\
& =\frac{8505714-8494172}{\sqrt{(13640228-12802084)(5673024}-5635876)} \\
& =\frac{11542}{\sqrt{(838144) \cdot(37148)}} \\
& =\frac{11542}{\sqrt{31135373312}}
\end{aligned}
$$




$$
\begin{aligned}
& =\frac{11542}{176452 \cdot 18421} \\
& =0,65411488 \\
& =0,654
\end{aligned}
$$

Dari hasil perhitungan di atas, didapat nilai koefesien korelasi sebesar $r=$ 0,654.dengan interpretasi hubungan antara kualitas pelayanan terhadap kepuasan nasabah kuat. Sehingga penulis dapat menyimpulkan dan menggabungkan dengan hasil uji Regresi Linier Sederhana bahwa terdapat pengaruh positif kuat antara kualitas pelayanan terhadap kepuasan nasabah PT. BPR Prima Kredit Mandiri cabang Ciputat Tangerang Selatan.

\section{3). Hasil Uji Determinasi}

Selanjutnya setelah mendapatkan hasil perhitungan koefesien korelasi product moment maka penulis melakukan perhitungan koefesien determinasi (KD) untuk mengetahui besarnya pengaruh variabel kualitas pelayanan terhadap kepuasan nasabah. (dalam bentuk persentase), sebagai berikut:

$R=r^{2} \times 100$

Dimana :

$\mathrm{R}=$ Korelasi Determinasi yang dicari

$\mathrm{R}=0,654$ (Koefisien korelasi)

$R=0,654^{2} \times 100 \%$

$\mathrm{R}=0,427716 \times 100 \%$

$\mathrm{R}=42,7716$

$\mathrm{R} \quad \mathbf{4} \mathbf{4 2 , 8} \%$

Berdasarkan perhitungan di atas, didapat koefesien determinasi $R=42,8 \%$ maka besarnya pengaruh kualitas pelayanan terhadap kepuasan nasabah sebesar $42,8 \%$ dan sisanya $57,2 \%$ dipengaruhi oleh faktor-faktor lain yang tidak diteliti penulis.

\section{4). Hasil Uji Hipotesis (Uji t)}

Selanjutnya dilakukan uji hipotesis (uji t) untuk mengetahui apakah kualitas pelayanan mempunyai pengaruh signifikan atau tidak terhadap kepuasan nasabah, maka uji hipotesis dalam penelitian ini sebagai berikut : 
a). Pengujian Hipotesis

Kriteria pengujian hipotesis

$\mathrm{Ho}=0$ : Tidak terdapat pengaruh positif dan signifikan antara kualitas pelayanan terhadap tingkat kepuasan nasabah PT. BPR Prima Kredit Mandiri cabang Ciputat Tangerang Selatan.

$\mathrm{Ha}=0$ : Terdapat pengaruh positif dan signifikan antara kualitas pelayanan terhadap tingkat kepuasan nasabah PT. BPR Prima Kredit Mandiri cabang Ciputat Tangerang Selatan.

b). Menentukan $t_{\text {hitung }}(u j i t)$

$$
\mathrm{t} \quad=\frac{r \sqrt{n-2}}{\sqrt{1-r^{2}}}
$$

Diketahui :

$$
\begin{aligned}
& \mathrm{t}=\text { Nilai } t_{\text {hitung }} \\
& \mathrm{r}=0,654 \\
& \mathrm{n}=98 \\
&=\frac{0,654 \sqrt{98-2}}{\sqrt{1-(0,654)^{2}}} \\
&=\frac{0,654 \sqrt{96}}{\sqrt{1-0,427716}} \\
&=\frac{0,654 \cdot 9,797958971}{\sqrt{0,327716}} \\
&=\frac{6,407865167}{\sqrt{0,5724648461}} \\
&=11.19346491 \\
& \mathrm{t}_{\text {hitung }}=11,193
\end{aligned}
$$

Sedangkan untuk menentukan besarnya $t_{\text {tabel }}$ dicari dengan menggunakan microsoft excel dengan rumus sebagai berikut :

$$
\begin{aligned}
t_{\text {tabel }} & =t(\alpha) \cdot(n-2) \\
& =t(5 \%) \cdot(98-2) \\
& =t(0,05) \cdot 96 \\
& =1,6609
\end{aligned}
$$

Dengan demikian, didapat dari hasil perhitungan di atas $t_{\text {hitung }}>t_{\text {tabel }}$ yaitu 11,,193 > 1,6609 yang artinya Ho ditolak dan Ha diterima, artinya terdapat pengaruh yang signifikan antara kualitas pelayanan terhadap kepuasan nasabah pada PT.BPR Prima Kredit Mandiri cabang Ciputat Tangerang Selatan. 


\section{G. Kesimpulan}

1. Kualitas pelayanan yang diberikan PT. BPR Prima Kredit Mandiri cabang Ciputat Tangerang Selatan dipersepsikan Baik (B) oleh nasabah. Hal itu dapat dilihat dari nilai rata-rata score variabel kualitas pelayanan sebesar 3,67 ada pada interval 3,40 - 4,19 dengan kategori Baik (B).

2. Kepuasan nasabah PT. BPR Prima Kredit Mandiri cabang Ciputat Tangerang Selatan dipersepsikan Puas (P). Hal itu dapat dilihat dari nilai rata-rata score variabel kepuasan nasabah sebesar 4,03 ada pada interval 3,40 - 4,19 dengan kategori Puas $(P)$.

3. Terdapat pengaruh positif kuat dan signifikan antara kualitas pelayanan terhadap kepuasan nasabah PT. BPR Prima Kredit Mandiri cabang Ciputat Tangerang Selatan. Hal itu dapat di lihat dari nilai koefesien regresi linier sederhana $Y=23,7+0,013 X$. Nilai koefesien korelasi product moment $r=0,654$. Nilai Koefesien determinasi $K D=42,8 \%$. Nilai $t_{\text {hitung }}>\mathrm{t}_{\text {tabel }}(11,193>1,6609)$.

\section{H. Daftar Pustaka}

Ambarawati, Yulian Belinda. (2014). Pengaruh Kualitas Pelayanan Terhadap Kepuasan Nasabah PT Bank Central Asia (BCA), Tbk Cabang Undaan Surabaya. Jurnal Akrual Akuntansi STIE Perbanas Surabaya. E-ISSN: 2502-6380.

Angelova Biljana \& Jusuf Zekiri. (2011). Measuring Customer Satisfaction with Service Quality, Trust, and Customer Satisfaction on Customers Loyalty. Abac Journal Vol. 29, No. 1,pp. 24-38.

Fogli, L. (2006). Customer Service Delivery. San Francisco: Jossey-Bass .

Ikatan Bankir Indonesia (IBI). (2014). Mengelola Kualitas Layanan Perbankan. Edisi 1, Jakarta: PT Gramedia Pustaka Utama.

Kasmir, (2013). Bank Dan Lembaga Keuangan Lainnya. Edisi 1, Cetakan 13, Jakarta:Penerbit Rajawali Pers.

Kertajaya, Hermawan. (2015). Marketing In Challenging Times. Jakarta: Penerbit PT

Koestanto dan Yuniati. (2014). Pengaruh Kualitas pelayanan Terhadap Kepuasan Pelanggan Pada bank Jatim Cabang Klampis Surabaya. Jurnal IImu \& Riset Manajemen Vol.3 No.10. 
Kotler, Philip \& Gary Amstrong. (2013). Principles Of Marketing, Eisi 5 England: Pearson Education Limited.

Kotler, Philip \& Kevin Lane Keller. (2013). Marketing Management, England: Pearson Horizon.

Tjiptono, Fandy. (2008). Pemasaran Strategik. Yogyakarta, Penerbit CV Andi Offset. Sallis, Edward. (2011). Total Quality Management In Education, Manajemen Mutu Terpadu Pendidikan. Alih Bahasa Ahmad Ali Riyadi. Jogjakarta: IRCiSoD.

Sugiyono. (2013). Metode Penelitian Bisnis, Bandung:Alfabeta.

Supranto J \& Nandan Limakrisna. (2013). Petunjuk Praktis Penelitian IImiah Untuk Menyusun Skripsi Tesis Dan Disertasi, Jakarta:Mitra Wacana Media.

Wijayanto, Kusuma. (2015). Pengaruh Kualitas Pelayanan Terhadap Kepuasan dan Loyalitas Nasabah Bank. Jurnal Daya saing Ekonomi Manajemen Vol. 17, No. 1, Juni 2015. Program Pascasarjana Magister Manajemen Universitas Muhammadiyah Surakarta.

Winkle. (2014). Psikologi Pengajaran. Cetakan Ke-1.Yogyakarta Penerbit Sketsa.

Yaqin dan Ilfitriah. (2014). Pengaruh Kualitas Pelayanan Terhadap Kepuasan dan Loyalitas Nasabah bank Pengguna E-banking di Surabaya. Journal usiness and banking. Vol.4 No. 2. STIE Perbanas Surabaya.

Yulianti, Fadma. (2013). Pengaruh Kualitas Pelayanan Terhadap Kepuasan Nasabah Tabungan Pada bank Panin Tbk KCP A. Yani Banjarmasin.Jurnal Spread Vol. 3, No. 2 STIE Indonesia Banjarmasin.

Yulinda. (2013). Analisis Pengaruh Kualitas Pelayanan Terhadap Kepuasan Nasabah Kredit Sumut Sejahtera I Pada PT ank Sumut Cabang Utama Medan. Jurnal Ekonomi Fakultas Ekonomi Sumatera Utara. Vol.16 N0. 1. 